\title{
STRATEGIC PLACE TRIANGLE PENGEMBANGAN POTENSI KAWASAN PARIWISATA BOJONEGERO
}

\author{
Muchammad Nurif, Soedarso, Suyanto, Wahyuddin
}

\begin{abstract}
Abstrak
Kabupaten Bojonegoro ditetapkan sebagai salah satu Daerah Tujuan Wisata (DTW) di Jawa Timur karena memiliki potensi obyek wisata alam dan budaya yang telah mendapatkan perhatian wisatawan nusantara pada umumnya. Dalam kebijakan pengembangan yang tertuang dalam Rencana Induk Pengembangan Pariwisata (RIPP) Jawa Timur 1999-2015 Kabupaten Bojonegoro meskipun bukan sebagai gerbang utama namun memiliki peran strategis untuk mendorong pertumbuhan kawasan di sekitarnya.

Dalam penelitian, peneliti melakukan pemetakan perubahan lingkungan eksternal, pemetakan pesaing dan pelanggan, analisis internal, dan analisis TOWS. Selanjutnya akan dirumuskan Strategic Place Triangle. Yang dimaksud dengan Strategic Place Triangle adalah suatu pendekatan strategi pemasaran wilayah yang mencakup tiga hal kunci, yaitu (1) Strategi yang mencakup Segmentasi-Targeting-Positioning, (2) Taktik yang mencakup DiferensiasiMarketing Mix-Selling, (3) Value yang mencakup Brand-Servis-Proses.

Analisis pemetaan terhadap lingkungan eksternal dan internal dengan menggunakan pendekatan Strategi Pemasaran Wilayah (Marketing Places) tersebut akan menghasilkan Positioning, Diferensiasi, dan Brand, bagi potensi kawasan pariwisata Bojonegoro. Positioning- nya adalah ibarat Bali bagi Jawa Timur dengan kekhasan tetap memegang nilai-nilai religi dan kultur lokal setempat. Diferensiasi-nya adalah one-stop-shopping services, pesona wisata yang tak berakhir, cantik alami, penduduknya yang santun, ramah dan mempesona. Brand-nya adalah Pesona Wisata Bojonegoro.
\end{abstract}

Kata Kunci : kawasan, pariwisata, Bojonegoro, Strategic Places Triangle, strategi, taktik, value

Ada tiga perubahan besar lansekap makro yang akan memengaruhi berbagai daerah di Indonesia dalam mengelola pemerintahannya. Pertama perubahan pada tingkat lokal, Kedua perubahan pada tingkat nasional, Ketiga perubahan pada tingkat global, sehingga berbagai perubahan besar tersebut akan memaksa berbagai daerah untuk memulai meninjau kembali pendekatan dan cara pandang mereka dalam mengelola daerah.

Perubahan pertama akan memaksa pemerintah daerah untuk mentransformasi diri dari bureaucratic-monopolistic government menjadi entrepreneurial-competitive government. Entrepreneurial government adalah pemerintah yang jeli dan selalu berpikir keras untuk melihat dan memanfaatkan 
peluang yang muncul untuk memakmurkan dan meningkatkan kualitas hidup masyarakatnya. Sementara, Competitive government adalah pemerintah daerah yang mendorong adanya persaingan wilayah di antara penyedia layanan publik dalam upaya mereka memberikan excellent services kepada para konstituennya, apakah itu tourist, traders, investors dan atau masyarakat luas.

Perubahan kedua mengharuskan mereka bermetamorfosis diri dari pemerintah daerah yang "cuek-bebal" menjadi pemerintah daerah yang berorientasi pelanggan (customer-driven government) dan bertanggungjawab (accountable government) terhadap seluruh stakeholder-nya secara seimbang.

Sementara, perubahan besar ketiga akan mendorong pemerintah daerah untuk memulai mengevaluasi diri dari pemerintah yang hanya memiliki local orientation menjadi pemerintah yang memiliki global-cosmopolit orientation. Pemerintah daerah semacam ini memiliki wawasan global. Mereka membuka diri terhadap investor asing, perusahaan asing, kepemilikan asing, produk asing, teknologi asing, orang-orang terbaik asing, bahkan dari situ akan terjadi persaingan antar wilayah dengan wilayah lain, antar wilayah dengan negara dalam rangka menarik tourist, traders, dan investors baik dari dalam maupun luar negeri, sejauh itu semua memiliki kontribusi positif terhadap peningkatan kualitas hidup masyarakat.

Sebagai negara yang sedang berkembang, Indonesia saat ini tengah aktif mengembangkan diri dalam segala bidang. Pengembangan kegiatan-kegiatan di setiap sektor tentunya membutuhkan dana yang tidak sedikit. Untuk itu maka Indonesia mencari peluang lain dengan memanfaatkan sumber daya seoptimal mungkin. Salah satu sektor yang masih belum dioptimalkan pengembangannya adalah sektor pariwisata, meskipun dalam penyusunan kebijakannya, strategi untuk sektor ini telah sering dirumuskan, namun ternyata pelaksanaannya masih mengalami kendala seperti yang juga dialami oleh Pemerintah Kabupaten Bojonegoro.

Gejala ini perlu diatasi dengan mengarahkan para wisatawan ke daerahdaerah tujuan wisata potensi lainnya. Daerah-daerah tujuan wisata yang diperkirakan memiliki potensi pariwisata diharapkan dapat segera dikembangkan dan mampu menghasilkan keuntungan. Hal ini merupakan peluang emas yang segera bisa 
dimanfaatkan. Akan tetapi pemanfaatan peluang tanpa perencanaan yang matang bisa mendatangkan petaka.

Sektor pariwisata merupakan salah satu sektor strategis dalam menggerakkan perekonomian Indonesia dan menjadi bagian dari perekonomian global. Berlangsungnya revolusi 3T, transport, telecomunication, tourism, menunjukkan bahwa kegiatan pariwasata telah menjadi salah satu kekuatan yang mampu mempercepat penyatuan dunia dalam integrasi ekonomi dan pergerakan manusia lintas daerah dan bahkan lintas negara (Rusman, 2004).

Melihat posisi strategis wilayah Kabupaten Bojonegoro yang mempunyai luas wilayah $2.384,02 \mathrm{~km}^{2}$, dengan total populasi 1.213 .000 jiwa (2003) dan kepadatan 508,8 jiwa $/ \mathrm{km}^{2}$. Kabupaten Bojonegoro terdiri dari 27 kecamatan yang terbagi dalam 420 desa dan 11 Kelurahan. Kabupaten Bojonegoro berbatasan dengan Kabupaten Tuban di utara, Kabupaten Lamongan di timur, Kabupaten Nganjuk, Kabupaten Madiun, dan Kabupaten Ngawi di selatan, serta Kabupaten Blora (Jawa Tengah) di barat. Bagian barat Bojonegoro (perbatasan dengan Jawa Tengah) merupakan bagian dari Blok Cepu, salah satu sumber deposit minyak bumi terbesar di Indonesia.

Kabupaten Bojonegoro ditetapkan sebagai salah satu Daerah Tujuan Wisata (DTW) di Jawa Timur oleh Pemerintah, disamping itu Kabupaten Bojonegoro merupakan wilayah yang memiliki potensi obyek wisata alam dan budaya telah mendapatkan perhatian wisatawan nusantara pada umumnya dan keadaan ini ditunjang oleh beberapa faktor antara lain: a) keadaan topografis; b) keadaan geografis; c) keadaan sosial budaya; d) iklim, fauna dan kekayaan alam.

Unsur yang sangat penting dalam pengembangan kepariwisataan salah satunya adalah pengembangan kawasan wisata yang sesuai dengan keinginan atau preferensi konsumen. Dalam pengertian yang lebih luas kawasan pariwisata adalah sesuatu yang dikonsumsikan oleh wisatawan mulai dari saat wisatawan meninggalkan tempat tinggalnya, selama perjalanan di obyek wisata yang dituju hingga kembali ke tempat tinggalnya.

Pengembangan kawasan wisata yang akan dilakukan harus melihat semua potensi yang ada di lingkungan sendiri maupun faktor lingkungan eksternal yang 
ada. Hal ini mengingat bahwa adanya kecenderungan semakin kuatnya persaingan antar wilayah dalam rangka menarik tourits, traders, dan investors (TTI) baik dari dalam maupun luar negeri.

Secara umum, strategi pengembangan yang diterapkan dalam Rencana Induk Pengembangan Pariwisata (RIPP) Pemerintah Propinsi Jawa Timur maupun Pemerintah Kabupaten Bojonegoro masih menerapkan strategi yang bersifat sektoral dan spasial. Sehingga dalam strategi ini tidak dijelaskan bagaimana pentingnya analisis dan pemetakan terhadap pesaing dan pelanggan. Padahal pemasar kawasan pariwisata perlu melakukan analisis dan pemetakan terhadap pesaing dan pelanggan. Dimana analisis pesaing dan lingkungan persaingan dilakukan untuk memahami arena persaingan antar kawasan pariwisata berikut berbagai kekuatan yang memengaruhinya, mengetahui faktor-faktor yang menentukan kesuksesan dalam bersaing, dan mengumpulkan informasi yang mendalam mengenai masing-masing pesaing, yang akan digunakan untuk melakukan benchmarking dan merumuskan keunggulan kompetitif suatu kawasan pariwisata.

Memasarkan suatu kawasan pariwisata daerah juga berarti mendesain suatu kawasan agar mampu memenuhi dan memuaskan keinginan dan ekspektasi pelanggannya. Siapa pelanggan suatu kawasan pariwisata daerah ? Yang pertama tentu saja penduduk dan masyarakat daerah tersebut yang membutuhkan layanan publik yang memadai. Kedua apa yang disebut TTI (trader, tourist, investor) baik dari dalam maunpun luar daerah, Ketiga, talent (SDM berkualitas), developer (pengembang), organizer (event organizer) - disingkat menjadi TDO - dan seluruh pihak yang memiliki kontribusi dalam membangun keunggulan bersaing suatu kawasan pariwisata.

Dalam konteks pengembangan kawasan pariwisata Kabupaten Bojonegoro saat ini, pendekatan ini sangat penting karena hingga saat ini para pemasar di daerah masih belum memiliki tool memadai yang dapat mereka gunakan untuk membangun daya saing dan mengembangkan serta memasarkan kawasan pariwisatanya ke pelanggan yang mereka bidik.

Mengingat hal tersebut, maka dalam penelitian ini, coba diajukan sebuah pendekatan mengenai bagaimana strategi untuk memasarkan kawasan pariwisata 
daerah dengan menggunakan pendekatan Marketing Places. Dan diharapkan model pendekatan ini dapat dimanfaatkan oleh pengambil keputusan (Pemda Bojonegoro) sebagai Platform dalam mengelola dan mengembangkan kawasan pariwisata untuk mengantisipasi berbagai perubahan besar diatas. Dengan pendekatan yang sederhana ini dapat memberikan gambaran mengenai siapa pelaku pemasaran kawasan pariwisata daerah, siapa pelanggan kawasan pariwisata daerah, dan agenda besar apa yang harus dilakukan oleh daerah untuk mengembangkan kawasan pariwisata daerah, sehingga memiliki daya saing yang kokoh dan kuat.

Dari latar belakang diatas dapat dirumuskan masalah penelitian sebagai berikut:

“ Bagaimana Merumuskan Strategi Pengembangan Kawasan Pariwisata Bojonegoro dengan Menggunakan Pendekatan Marketing Places".

Sementara batasan lingkup permasalahan yang akan diteliti adalah potensi kawasan pariwisata Kabupaten Bojonegoro yang meliputi, kawasan wisata Kayangan Api, kawasan wisata Waduk Pacal, kawasan wisata Tirtawana Dander, kawasan wisata Angling Dharma, dan kawasan Wisata Bendung Gerak. Yang dimaksud pariwisata adalah serangkaian kegiatan perjalanan yang dilakukan oleh perorangan atau keluarga atau kelompok dari tempat tinggal asalnya ke berbagai tempat lain dengan tujuan melakukan kunjungan wisata dan bukan untuk bekerja atau mencari penghasilan di tempat tujuan.

Sedangkan pendekatan Marketing Places (Pemasaran Wilayah) yang dimaksud adalah perumusan Strategic Place Triangle. Strategic Place Triangle adalah suatu pendekatan strategi pemasaran wilayah yang mencakup tiga hal kunci. Pertama Strategi yang mencakup Segmentasi-Targeting-Positioning. Kedua adalah Taktik yang mencakup Diferensiasi-Marketing Mix-Selling. Ketiga adalah Value yang mencakup Brand-Servis-Proses.

Tujuan dari penelitia ini adalah: a) Untuk menganalisis perubahan lingkungan eksternal dan kondisi lingkungan internal Potensi kawasan Pariwisata Bojonegoro. b) Untuk memetakan pesaing dan pelanggan Potensi kawasan Pariwisata Bojonegoro. c) Untuk merumuskan Strategic Place Triangle (SPT) bagi Potensi kawasan Pariwisata Bojonegoro. d) Untuk merumuskan rencana strategik pemasaran potensi kawasan pariwisata Bojonegoro 


\section{Model Strategic Place Triangle (SPT)}

Strategi dalam pengertian strategi pemasaran kawasan pariwisata daerah tidak lain adalah perumusan apa yang disebut dengan Strategic Place Triangle. Menurut Hermawan Kartajaya. (2005) sesuai namanya, Strategic Place Triangle mencakup tiga hal kunci. Pertama adalah Strategi yang mencakup SegmentasiTargeting-Positioning. Kedua adalah Taktik yang mencakup DiferensiasiMarketing Mix-Selling. Dan ketiga adalah Value yang mencakup Brand-ServisProses. Dari kesembilan elemen pemasaran tersebut, kalau diperas lagi maka akan didapatkan tiga komponen inti yaitu; penetapan Positioning, pengembangan Diferensiasi, dan upaya membangun Merek (Brand) kawasan pariwisata daerah yang sering disebut "segitiga" PDB kawasan pariwisata daerah. Positioning adalah upaya untuk membangun suatu posisi tertentu di benak pelanggan. Diferensiasi adalah upaya untuk membedakan diri melalui pemberian value proposition yang unik dan berbeda dari apa yang diberikan oleh pesaing. Dan membangun merek tidak lain adalah membangun awareness, asosiasi merek, persepsi kualitas, dan loyalitas merek. Positioning yang tepat yang ditopang oleh diferensiasi yang kokoh dapat menghasilkan merek suatu kawasan pariwisata yang kokoh dan kredibel dimata pelanggan. Melengkapi Segitiga PDB tersebut,suatu kawasan pariwisata juga harus melakukan segmentasi pasar dan secara focus memilih pelanggannya. Suatu kawasan pariwisata juga harus menjalankan marketing mix (4P: Product, Price, Place, Promotion) dan strategi penjualan (selling strategy). Dan terakhir, suatu kawasan pariwisata juga harus memperlancar proses di dalam organisasi dan memperkuat layanan (customer service) kepada pelanggan kawasan pariwisata.

\section{Strategic-Entrepreneurial}

Menurut Hermawan (2005), saat ini daerah harus mulai menggeser pendeka tannya dalam hal pengelolaan dan pengembangan ekonomi daerah, dari pendekatan yang birokratis ke pendekatan strategic entrepreneurial.

Pendekatan birokratis adalah sebuah pendekatan pengelolaan daerah yang picik, karena selalu berorientasi pada prosedur dan aturan baku birokrasi yang menyebabkan daerah kehilangan kepekaan terhadap kebutuhan konstituennya. 
Pendekatan strategic entrepreneurial bersifat pragmatis karena selalu berorientasi hasil dan peka terhadap setiap peluang, selalu fokus pada kebutuhan dan ekspektasi konstituennya dan yang tidak kalah pentingnya responsif terhadap setiap perubahan yang terjadi dalam lingkungan makro. Dengan pendekatan ini menuntut tiga elemen penting dalam perencanaan daerah yaitu, visi dan tujuan jangka panjang daerah, upaya membangun entrepreneurial ke segenap SDM daerah dan perumusan strategi daerah yang solid. Dengan tiga hal tesebut, alokasi sumber daya daerah akan efektif dan terarah sehingga keunggulan daerah dapat dibangun.

Membangun keunggulan bersaing suatu kawasan menurut Michael Porter, dalam Hermawan Kartajaya (2005), tidak lain adalah upaya meningkatkan produktivitas (nilai output yang dihasilkan per unit input yang digunakan) yang pada gilirannya akan menaikkan kualitas dan standart hidup masyarakat dalam jangka panjang. Dasar pemikiran dari model ini adalah upaya menarik sumber daya terbaik baik dari dalam maupun luar daerah (nasional maupun global) sebagai landasan untuk memacu produktivitasnya. Menurut Hermawan Kartajaya (2005), secara garis besar model ini berisi tiga langkah strategis. Pertama menjadi tuan rumah yang baik (Be a good host) bagi pelanggan . Kedua, memperlakukan mereka secara baik (Treat your guest properly). Dan ketiga , membangun sebuah "rumah" yang nyaman bagi mereka (Building a home sweet home). Untuk lebih jelasnya dapat dilihat pada gambar di bawah ini : 


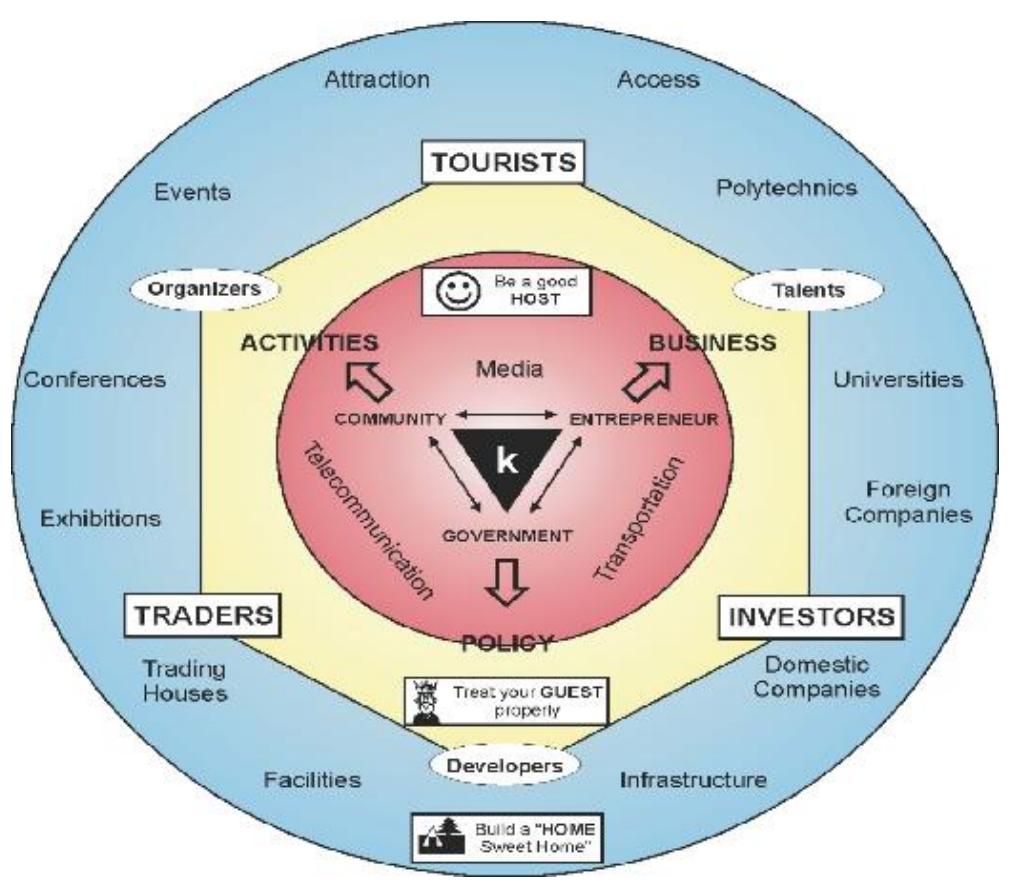

Gambar : Langkah Strategis Memasarkan Kawasan Pariwisata kepada TTITDO.

\section{Pemasaran Wilayah (Marketing Places)}

Marketing sebagai sebuah fungsi sedang sekarat dan kehilangan pijakannya. Melalui sebuah model Sustainable Market-ing Entreprise, Philip Kotler dkk (2003) berpendapat bahwa market-ing harus menjadi sebuah konsep bisnis strategis yang bertujuan untuk meraih kepuasan berkelanjutan bagi ketiga stakeholder utama: pelanggan, orang-orang dalam organisasi itu, serta para pemegang saham. Marketing adalah jiwanya, bukan sekadar bagian dari tubuh organisasi, maka dari itu setiap orang dalam organisasi harus menjadi seorang marketer.

Dalam bukunya yang lain berjudul, Marketing Management, Philip Kotler, berpendapat " Marketing is a social and managerial process by which individuala and group obtain what they need and want throuth creating and exchanging products and value with others". Disini pemasaran diartikan sebagai suatu proses social dengan mana individu dan kelompok mendapatkan apa yang mereka butuhkan dan inginkan dengan menciptakan dan mempertukarkan produk dan nilai dengan individu dan kelompok lainnya.

Menurut Winardi (2001) dalam bukunya yang berjudul azas-azas marketing mengatakan, " Pemasaran adalah terdiri dari tindakan yang menyebabkan 
berpindahnya hak milik atas benda-benda dan jasa-jasa dan menimbulkan hak milik atas benda-benda dan yang menimbulkan distribusi fisiknya".

Disini pemasaran adalah suatu sistem total dari kegiatan usaha yang tujukan untuk merencanakan, memutuskan harga, mempromosikan dan mendistribusikan barang dan jasa yang dapat memuaskan kebutuhan pembeli potensial.

Basu Swasta DH dan Irawan (1992) dalam bukunya, Manajemen Pemasaran Modern mendefinisikan : “Pemasaran adalah salah satu dari kegiatan pokok yang dilakukan para pengusaha untuk mempertahankan kelnagsuungan hidup, berkembang dan mendapatkan laba”.

Selanjutnya, market-ing dapat dipandang menurut tiga dimensi strategis: Outlook, Architecture, dan Scorecard. Ini melibatkan tiga aktivitas strategis: melaksanakan suatu kajian tentang lanskap bisnis dimasa mendatang; merancang serta melaksanakan arsitektur bisnis melalui: segmentasi, targeting, positioning, diferensiasi, marketing mix, selling, brand, service dan proses; semua unsur ini disebut sebagai nine core elements of architecture ( sembilan unsur inti arsitektur). Kesembilan unsur ini merupakan hal yang esensial bagi perusahaan manapun. Kita tidak dapat mengabaikan yang manapun dari mereka. Secara bersama-sama, mereka membentuk "grand design" dari perusahaan (Pemda) akhirnya menyeimbangkan proposisi nilai bagi para stakeholder. (Philip Kotler, dkk, 2003).

Dalam skala yang lebih luas (global-cosmopolit orientation) pemerintah daerah harus berupaya keras membangun kemampuan, inovasi, kapabilitas operasional, dan jaringan berskala global sebagai jembatan bagi mereka untuk dapat berpartisipasi dan mengambil keuntungan maksimal dari terbentuknya ekonomi global.

\section{PEMBAHASAN HASIL YANG DICAPAI}

Untuk dapat memenuhi tujuan penelitian, dalam penelitian ini menggunakan metode penelitian preskriptif dan pendekatan Strategi Pemasaran Wilayah (Marketing Places). Metode preskriptif digunakan untuk mendapatkan suatu formula pemasaran kawasan pariwisata Kabupaten Bojonegoro yang dapat 
diberikan untuk rekomendasi bagi pemerintah daerah sebagai decision maker maupun pelanggan daerah. Pelanggan yang dimaksud meliputi penduduk dan masyarakat daerah tersebut, Trader, Tourist, Investor (TTI), dan Talent, Developer, Organizer (TDO) serta seluruh pihak yang memiliki kontribusi dalam membangun keunggulan bersaing. Sedangkan pendekatan Strategi Pemasaran Wilayah yang dimaksud adalah perumusan Strategic Place Triangle. Strategic Place Triangle adalah suatu pendekatan strategi pemasaran wilayah yang mencakup tiga hal kunci. Pertama Strategi yang mencakup Segmentasi-Targeting-Positioning. Kedua adalah Taktik yang mencakup Diferensiasi-Marketing Mix-Selling. Ketiga adalah Value yang mencakup Brand-Servis-Proses.

Melengkapi Segitiga PDB tersebut, suatu kawasan pariwisata Bojonegoro juga harus melakukan segmentasi pasar dan secara fokus memilih pelanggannya. Suatu kawasan pariwisata juga harus menjalankan marketing mix (4P: Product, Price, Place, Promotion) dan strategi penjualan (selling strategy). Dan terakhir, suatu kawasan pariwisata juga harus memperlancar proses di dalam organisasi dan memperkuat layanan (customer service) kepada pelanggan kawasan pariwisata Bojonegoro.

Pemilihan pendekatan ini didasarkan atas pertimbangan bahwa selama ini dalam memasarkan potensi kawasan pariwisata daerah lebih bersifat inward looking yaitu hanya melihat potensi yang dimiliki oleh kawasan itu, tapi kurang memperhatikan sudut pemasaran itu sendiri (outward looking). Mengacu pada metode preskriptif dan pendekatan Strategi Pemasaran Wilayah (Marketing Places) diatas, maka aspek-aspek dalam penelitian adalah sebagai berikut:

I. Memetakan Perubahan Lingkungan Eksternal, yang meliputi:

a. Analisis Perubahan Teknologi

b. Analisis Perubahan Politik dan Regulasi

c. Analisis Perubahan Sosial Budaya

d. Analisis Perubahan Ekonomi

e. Analisis Perubahan Pasar

II. Memetakan Pesaing dan Pelanggan, yang meliputi : 


\section{a. Analisis Pesaing}

1. Formulasi Keunggulan Bersaing

a. Tersedianya sumber daya manusia yang menguasai teknologi.

b. Jaminan kestabilan keamanan wilayah.

c. Mengakomodir kebutuhan para investor dalam berinvestasi.

d. Membangun infrastruktur komunikasi serta transportasi yang menunjang empat sektor utama tersebut.

e. Memberikan kemudahan layanan perijinan berinvestasi.

Dari uraian diatas dapat diidentifikasikan empat besar pesaing kawasan pariwisata Bojonegoro beserta keunggulan dan kelemahannya. Banyuwangi ternyata menjadi pesaing utama karena memiliki banyak potensi wisata baik wisata alam, budaya maupun wisata minat khusus. Di samping itu juga Banyuwangi memiliki kedekatan dengan Bali. Untuk lebih jelasnya dapat dilihat dalam tabel di bawah ini.

Tabel. Empat Besar Kawasan Pariwisata Pesaing

\begin{tabular}{|l|l|l|}
\hline \multicolumn{1}{|c|}{$\begin{array}{c}\text { Kawasan } \\
\text { Pariwisata } \\
\text { Pesaing }\end{array}$} & \multicolumn{1}{|c|}{ Keunggulan } & \multicolumn{1}{c|}{ Kelemahan } \\
\hline 1. Banyuwangi & $\begin{array}{l}\text { Memiliki banyak potensi } \\
\text { wisata alam, budaya, dan } \\
\text { minat khusus. Lebih dekat } \\
\text { dengan Bali }\end{array}$ & $\begin{array}{l}\text { Kondisi alam pegunungan } \\
\text { dan laut yang } \\
\text { membahayakan. }\end{array}$ \\
\hline 2. Lamongan & $\begin{array}{l}\text { Memiliki banyak potensi } \\
\text { wisata alam, dan minat } \\
\text { khusus. }\end{array}$ & $\begin{array}{l}\text { Nuansa wisata lebih } \\
\text { mengandalkan nuansa laut. }\end{array}$ \\
\hline 3. Malang & $\begin{array}{l}\text { Memiliki banyak potensi } \\
\text { wisata alam, dan minat } \\
\text { khusus. }\end{array}$ & $\begin{array}{l}\text { Kondisi kawasan pariwisata } \\
\text { yang ada terpencar-pencar. }\end{array}$ \\
\hline 4. Tuban & $\begin{array}{l}\text { Memiliki banyak potensi } \\
\text { wisata alam (terutama gua) } \\
\text { dan religi. }\end{array}$ & $\begin{array}{l}\text { Hanya mengandalkan poten } \\
\text { si wisata alam dan religi. }\end{array}$ \\
\hline
\end{tabular}

Sumber: data diolah 2015

\section{b. Analisis Pelanggan}

Pelanggan kawasan pariwisata dapat dibagi dua kelompok besar, yaitu pelanggan utama (primary customers) yang mencakup pedagang, wisatawan, penanam modal (TTI) dan pelanggan sekunder (secondary customers) yang 
mencakup SDM berketrampilan, pengembang dan para pengelola event (TDO). Selain itu pelanggan dapat dikelompokkan menjadi pelanggan individu yang terdiri dari tourist dan talent dan pelanggan bisnis yang terdiri dari investor, trader, organizer, dan developer.

1. Karakteristik pelanggan individu (secara umum, perilaku pembelian dipengaruhi oleh faktor budaya, sosial, personal dan psikologi)

a. Umumnya tourist yang berkunjung ke kawasan pariwisata Bojonegoro adalah dalam rangka penelitian seperti ketika ditemukannya Api yang tidak kunjung padam yang diberi nama Kayangan Api. Dan adanya Tambang Minyak Tradisional.

b. Memiliki hubungan budaya atau sosial dengan komunitas masyarakat setempat;

c. Berada pada kelas masyarakat menengah;

d. Berasal dari wilayah Jawa Timur dan sekitarnya;

e. Sebagai daerah perlintasan Bali-Jogja, sering kali daerah lain disekitarnya dijadikan sebagai tempat persinggahan, termasuk Bojonegoro.

2. Karakteristik pelanggan bisnis (Investor, trader, organizer, dan developer).

a. Sebagian besar adalah para investor di sektor industri dan beberapa investor di sektor perdagangan ritel dan pariwisata, seperti Penggalian dan tambang minyak.

b. Investor di sektor industri dan perumahan (pemukiman) masuk dalam kreteria investor yang cukup sedang, terutama karena Bojonegoro merupakan kawasan alternatif dalam pengembangan di sektor ini setelah Gresik dan Lamongan.

c. Belum ada event organizer yang secara profesional mengelola pasar pariwisata hutan, sehingga memerlukan pengembangan lebih lanjut.

Sementara itu pengembangan kawasan pariwisata di wilayah Kabupaten Bojonegoro, bentuk peran serta pelanggan bisnis yang mungkin dikembangkan adalah : 
a. Consep Leasing, dimana badan usaha swasta menyewa suatu fasilitas pemerintah selama jangka waktu tertentu yang disepakati dan memperoleh pemasukan.

b. Consep Contract Operations, dimana pemerintah tetap mengendalikan badan usahanya dan meminta suatu institusi swasta untuk memberikan jasa manajemen atau jasa lainnya selama periode tertentu.

c. Penerapan konsep kerjasama Pemerintah-swasta yang meliputi kegiatan pembangunan yang kompleks, seperti pembangunan kota baru, peremajaan kota dan pembangunan kawasan industri, pembangunan kawasan pariwisata, dimana pemerintah membantu penyediaan lahan dan swasta merupakan pelaksana utama pembangunannya.

d. Melibatkan peran sektor informal dan masyarakat setempat dalam penyediaan fasilitas pelayanan wisata secara murah.

\section{Analisis Internal}

Dalam melakukan analisis lingkungan internal, beberapa langkah berikut harus dilakukan oleh pemasar kawasan suatu daerah. Pertama adalah melakukan audit terhadap sumber daya (resources) yang dimiliki, hal ini mencakup; sumber daya fisik (phisical resources); sumber daya manusia (human resources), dan sumber daya intangible (intangible resources). Dari langkah pertama terhadap analisis kawasan pariwisata Bojonegoro didapatkan;

1. Tersedianya sumber daya alam yang masih potensial dikembangkan terutama dengan mengakomodasikan teknologi ramah lingkungan.

2. Tersedianya sumber daya manusia dengan berbagai klasifikasi. Namun masih terbatas pada sumber daya manusia yang adaptif terhadap kemajuan teknologi.

3. Kawasan pariwisata, terutama kawasan wisata budaya dan wisata alam yang pengembangannya masih belum optimal.

Kedua mengidentifikasi berbagai kompetensi yang dimiliki oleh kawasan pariwisata Bojonegoro dilanjutkan dengan identifikasi kompetensi inti (core competence), yang mencakup; Government Leadership; culture \& values; industrial organization; social cohesion, didapatkan; 
1. Pemerintah Kabupaten Bojonegoro adalah pemerintahan yang adaptif terhadap perubahan.

2. Pemerintah Kabupaten Bojonegoro adalah pemerintahan yang cukup akomodatif terhadap kebutuhan terbentuknya lingkungan sadar pariwisata.

3. Budaya Jawa yang menjadi kultur utama dalam masyarakat Bojonegoro merupakan modal utama pengembangan kawasan pariwisata.

Kabupaten Bojonegoro memiliki kawasan pariwisata yang cukup potensial seperti wisata alam (hutan) maupun wisata budaya. Masalah kepariwisataan yang dihadapi saat ini adalah belum memadainya sarana dan prasarana penunjang kawasan wisata karena sebagian besar wilayahnya masih dalam kepemilikan PERHUTANI. Selain itu perlu adanya pembinaan terhadap masyarakat terutama masyarakat sekitar kawasan pariwisata untuk sadar wisata. Di antara kawasan pariwisata Bojonegoro yang dalam pengelolaan Dinas Kebudayaan dan Pariwisata Kabupaten Bojonegoro antara lain: 1) Kayangan Api, 2) Waduk Pacal, 3) Bendung Gerak, 4) Tirtawana, 5) Tambang Minyak Tradisional, 6) Makam Wali Kidangan, 7) kerajinan patung, 8) Kerajinanj Bubut Kayu, 9) Masjid menak Anggrung, 10) Ledre, 11) Kerajinan Seni Akar Kayu, 12) Masyarakat Samin, 13) Bati Jonegoroan, 14) Jambu Mayanggeneng, 15) Petilasan Angling Dharmo, 16) Blimbing Ngringinrejo, 17) Salak Wedi, 18) Pengrajin Tampar \& Pelepah Pisang, 19) Air Terjun Krondonan, 20) Desa Wisata Jono, 21) Sentra Batik Jonegoroan, 22) Klenteng Hok Swie Bio, 23) Batu Semar Alon-alon Kota, 24) Masjid Agung Darussalam, 25) Grebek Berkah Jonegaran.

\section{Analisis TOWS}

Untuk melakukan analisis SWOT/TOWS, langkah pertama adalah kita harus mengumpulkan berbagai perubahan lingkungan eksternal baik pesaing, investor, perubahan teknologi, politik-regulasi, sosial-budaya, ekonomi, dan pasar. Setelah kita kumpulkan perubahan tersebut kemudian kita bisa mengelompokkannya ke dalam perubahan yang menghasilkan peluang dan perubahan yang mendatangkan ancaman bagi kawasan pariwisata. Di samping itu, juga harus meninjau kondisi internal daerah baik berupa sumber daya maupun kompetensi yang dimiliki. Dari berbagai faktor internal daerah tersebut, harus dikelompokkan ke dalam faktor yang 
merupakan kekuatan dan faktor yang merupakan kelemahan kawasan pariwisata Bojonegoro. Tentu saja kekuatan dan kelemahan ini ditetapkan secara relatif terhadap pesaing.

Dari analisis SWOT/TOWS, maka dihasilkan strategi umum dalam rangka pengembangan kawasan pariwisata Bojonegoro sebagai berikut:

Tabel. Analisis TOWS Kawasan Pariwisata Bojonegoro

\begin{tabular}{|c|c|c|}
\hline Faktor Eksternal & 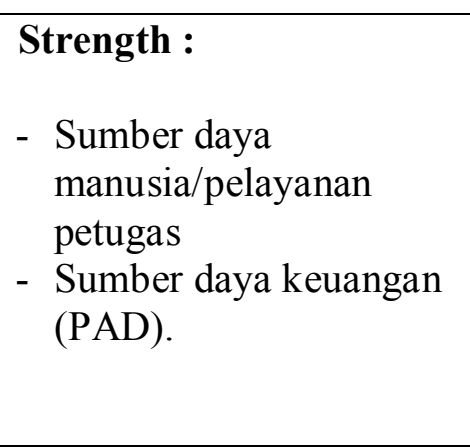 & $\begin{array}{ll}\text { Weakness : } \\
\text { - } & \text { Sumber daya fisik } \\
\text { (daya tarik, fasilitas } \\
\text { MCK, kebersihan) } \\
\text { - } & \text { Sumber daya } \\
\text { intangible } \\
\text { (kenyamanan dan } \\
\text { keamanan). } \\
\end{array}$ \\
\hline $\begin{array}{l}\text { Oportunity : } \\
\text { - Perubahan teknologi } \\
\text { - Perubahan social budaya } \\
\text { - Perubahan ekonomi } \\
\text { - Investasi }\end{array}$ & $\begin{array}{l}\text { Strategi SO : } \\
\text { - Memanfaatkan IT } \\
\text { untuk memasarkan } \\
\text { pariwisata } \\
\text { - Mengoptimalkan PAD } \\
\text { dan investor untuk } \\
\text { mengembangkan obyek } \\
\text { wisata }\end{array}$ & $\begin{array}{l}\text { Strategi WO : } \\
\begin{array}{l}\text { - } \\
\text { Mengoptimalkan } \\
\text { pameran kebudayaan } \\
\text { dan seni untuk menarik } \\
\text { pengu njung (touris) } \\
\text { - } \\
\text { Melakukan negosiasi } \\
\text { dengan investor untuk } \\
\text { mengembangkan } \\
\text { kawasan pariwisata }\end{array}\end{array}$ \\
\hline $\begin{array}{l}\text { Treath : } \\
\text { - Perubahan politik dan } \\
\text { regulasi } \\
\text { - Perubahan pasar } \\
\text { - Analisis pesaing } \\
\text { - Analisis pelanggan }\end{array}$ & $\begin{array}{l}\text { Strategi ST: } \\
\text { - Meningkatkan skill dan } \\
\text { wawasan. } \\
\text { pejabat/petugas } \\
\text { - Menarik pela nggan } \\
\text { luar daerah melalui } \\
\text { pemasangan poster dan } \\
\text { baliho diperbatasan } \\
\text { daerah. }\end{array}$ & $\begin{array}{l}\text { Strategi WT : } \\
\begin{array}{l}\text { - Meningkatkan daya } \\
\text { tarik wisata dengan } \\
\text { memperbaiki fasilitas, } \\
\text { pelayanan, dan } \\
\text { keamanan } \\
\text { - } \text { Melakukan studi } \\
\text { banding dengan daerah } \\
\text { lain/pesaing }\end{array}\end{array}$ \\
\hline
\end{tabular}

Sumber: Data diolah 2015 


\section{Analisis Perubahan Pasar}

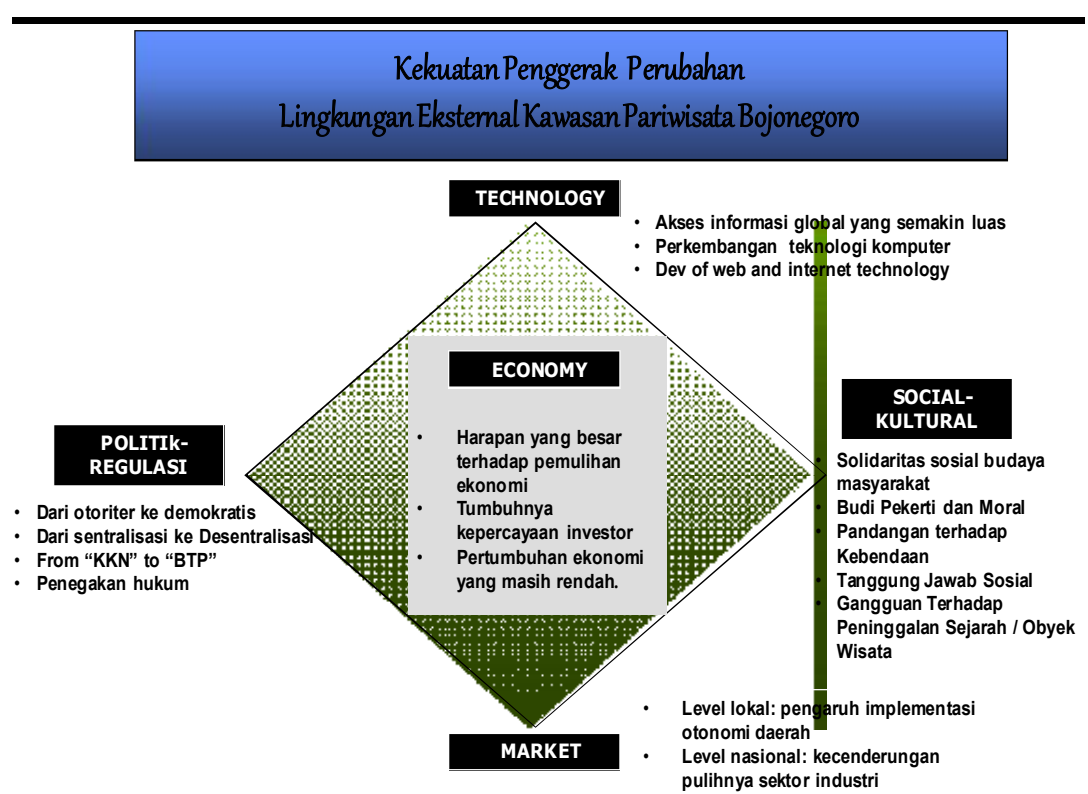

Sumber: Hermawan Kartajaya, Yuswohadi, Attracting-

Tourists,Traders,Investors, 2005 (Data diolah 2015

\section{Gambar. Berbagai Kekuatan Perubahan}

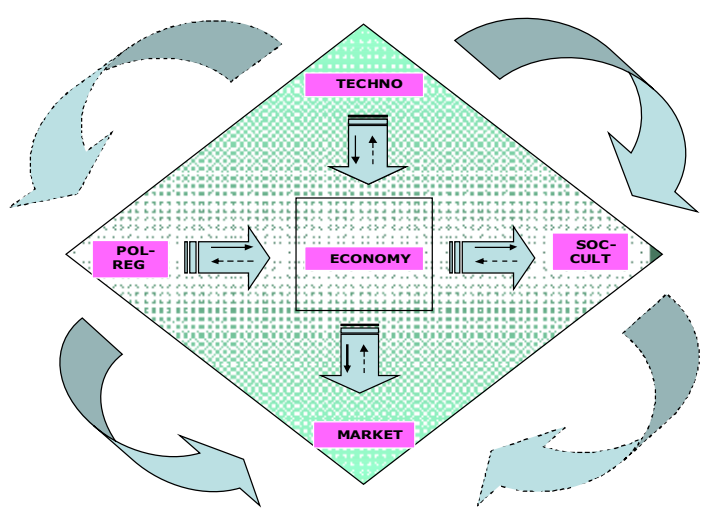

\section{Gambar. Empat Arus Utama Kekuatan Perubahan}

Arus utama kedua adalah "arus ke kanan", yang diwakili oleh interaksi kekuatan-kekuatan politik regulasi-ekonomi-sosial kultural. Perubahan politik pertama-tama muncul karena proses "buy-in" oleh manajemen kawasan pariwisata Bojonegoro yang akan memastikan kesatuan dan dukungan yang dibutuhkan untuk menjalankan sebuah perubahan. Begitu manajemen berkomitmen, program-program 
yang lebih bersifat ekonomis, seperti pengadopsian suatu strategi baru akan mudah diimplementasikan. Akhirnya sosial-budaya suatu kawasan harus disesuaikan untuk mendukung strategi baru itu supaya dapat menjamin keberhasilan implementasinya.

Mengacu pada proses tersebut, perubahan politik regulasi kerap muncul lebih dahulu, yang diikuti dengan perubahan ekonomi serta perubahan sosial dan kultural yang mennyertainya. Gerakan demokratisasi, misalnya, dapat mengkoordinasikan (Coordination) suatu sistem ekonomi yang sama sekali baru, lebih terbuka dan lebih transparan. Bagaimana sistem ekonomi ini berkembang selanjutnya akan mempengaruhi proses sofistifikasi masyarakat.

Arus utana ketiga adalah “ interaksi timbal balik" antara kekuatan-kekuatan teknologi dan sosial/kultural. Munculnya teknologi baru selalu mengakomodasi (Accomadation) masyarakat untuk menuju pada hal yang lebih baik karena teknologi baru membuat kehidupan lebih mudah dan lebih nyaman, yang pada gilirannya akan secara efektif mengubah cara hidup masyarakat. Sementara sebaliknya, gaya hidup masyarakat akan menginspirasi (Inspiration) perkembangan teknologi-teknologi baru. Misalnya, munculnya e-commerce telah menawarkan dan mengakomodasi suatu cara hidup alternatif bagi masyarakat. Orang sekarang dapat berbelanja, melakukan transaksi perbankan, bahkan melakukan kunjungan wisata dari komputer mereka.

Arus utama keempat adalah “ interaksi timbal balik " antara kekuatankekuatan politik regulasi dengan pasar. Perubahan dalam lingkungan politik dan hukum selalu meredefinisi (Redefinition) dinamika pasar. Deregulasi perijinan dan investasi, misalnya, mungkin akan mendorong terciptanya pasar-pasar baru serta munculnya pemain-pemain baru.

Analisis lingkungan eksternal mencakup tiga elemen besar, yaitu analisis perubahan (change), analisis pesaing (competitor), dan analisis pelanggan (customer) yang dalam konteks kawasan pariwisata Bojonegoro adalah tradertourist-investor-talent-developer-organizer (TTI-TDO). Analisis lingkungan ekstenal ini lebih lanjut dibagi menjadi lima aspek, yaitu analisis terhadap teknologi, politik-regulasi, sosial-budaya, ekonomi, dan pasar. Sementara itu analisis lingkungan internal mencakup analisis terhadap kondisi internal kawasan pariwisata 
Bojonegoro yang mencakup antara lain core competence, kondisi keuangan, produk unggulan, strength dan weakness kawasan pariwisata Bojonegoro dan sebagainya. Dan dilanjutkan dengan uraian mengenai analisis TOWS (threat, opportunity, strength, weakness). Dan yang terakhir dalam membangun dan mengembangkan strategi Marketing Places kawasan pariwisata Bojonegoro adalah merumuskan Strategic Place Triangle.

\section{MEMBANGUN VISI DAERAH}

Untuk memberikan fondasi bagi perumusan strategi, maka diperlukan visi sebagai basis penetapan tujuan dan target organisasi. Visi merupakan simpul atau starting point bagi seluruh upaya daerah dalam membangun strategi pemasaran.

Untuk memasarkan kawasan pariwisata Kabupaten Bojonegoro, maka perlu dibuat visi yang dirancang untuk meraih suatu tujuan di masa depan yang sangat menantang, pencapaian target yang tidak mudah, mampu merangsang antusiasme, komitmen dan kebanggaan bagi semua yang terlibat dengan arah yang jelas, realistis dan sederhana agar mudah dipahami, yaitu Pembangunan Kawasan pariwisata Kabupaten Bojonegoro Yang Terpadu dan Lestari Dengan Berlandaskan Nilai Agama dan Budaya Sebagai Sumber Penghidupan Bagi Kesejahteraan Masyarakat.

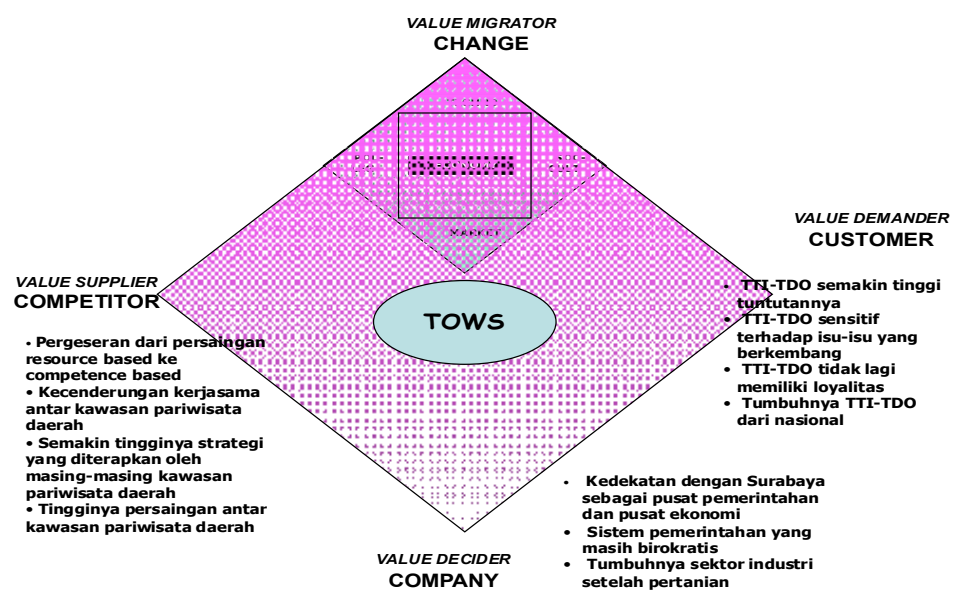

Sumber: Data diolah 2015 (Philip Kotler dan Hermawan Kartajaya, Rethingking Marketing- Sustainable Market-ing Enterprise di asia, 2003)

Gambar. 4C - Diamond 
Ancaman dan peluang yang datang dari lingkungan eksternal dan kekuatan dan kelemahan yang datang dari faktor internal sudah dipetakan, selanjutnya didapatkan gambaran mengenai posisi kita. Berdasarkan posisi itulah kita akan dapat menyusun strategi umum yang akan dijalankan untuk memenangkan persaingan. Hal ini dapat dilihat pada gambar di atas.

\section{STRATEGIC PLACE TRIANGLE}

Strategic Place Triangle mencakup tiga hal kunci. Pertama adalah Strategi yang mencakup Segmentasi-Targeting-Positioning. Kedua adalah Taktik yang mencakup Diferensiasi-Marketing Mix-Selling. Dan ketiga adalah Value yang mencakup Brand-Servis-Proses. Dari kesembilan elemen pemasaran tersebut, akan

didapatkan tiga komponen inti yaitu penetapan Positioning, pengembangan Diferensiasi, dan upaya membangun Merek (Brand) daerah, yang sering disebut "segitiga PDB" daerah.

Dalam kesembilan unsur diatas, terdapat suatu kaitan khusus antara brand, positioning, dan differentiotion yang merupakan inti dari Strategic Place Triangle dapat dilihat pada gambar di bawah ini. Brand harus diposisikan dengan jelas dalam benak pelanggan agar dapat memberikan identitas yang jelas. Positioning pada hakikatnya merupakan sebuah "janji” dari kawasan pariwisata Bojonegoro kepada pelanggannya.

Ketika Kawasan Pariwisata Bojonegoro memposisikan dirinya dalam benak pelanggan sebagai "Datanglah \&e Bojonegoro Setelah Bal", maka sesungguhnya ia menjanjikan kepada para pelanggan nya bahwa untuk dapat menikmati suasana eksotis setelah Bali, Anda bisa datang ke Bojonegoro. 


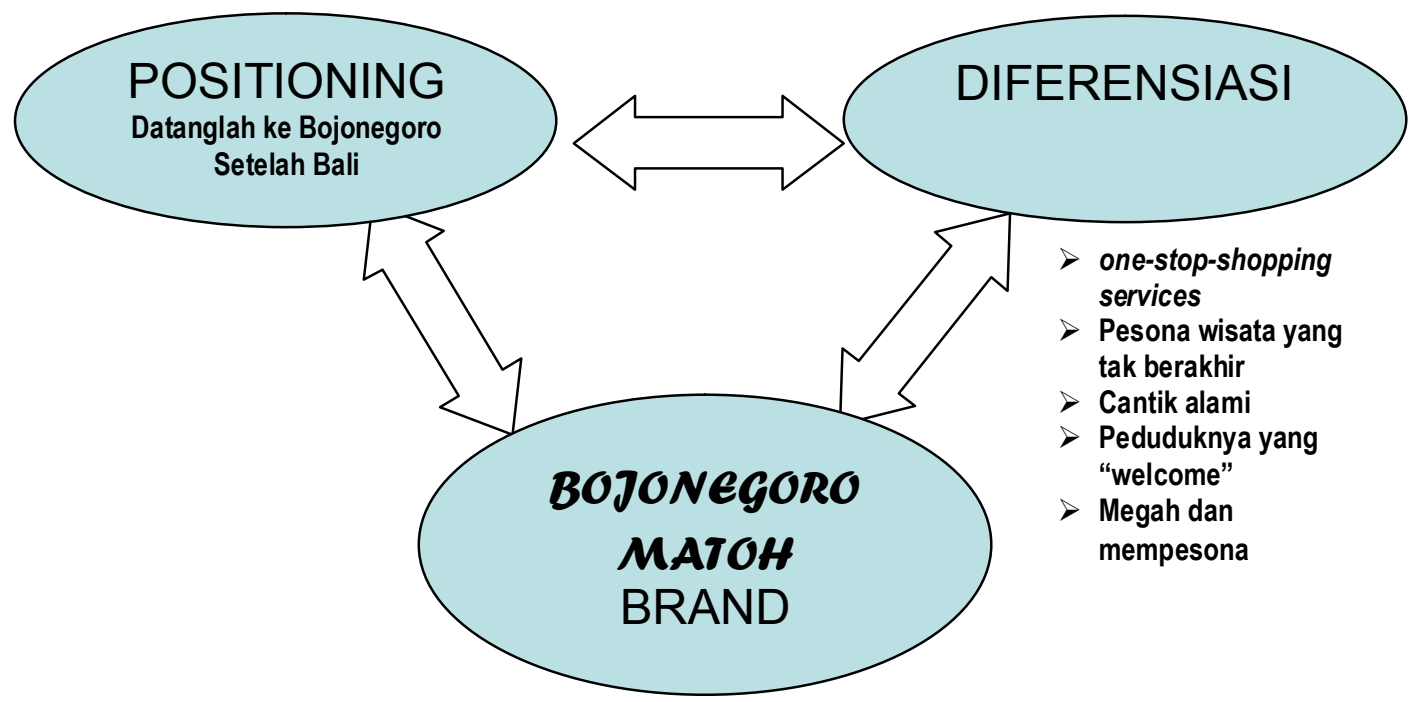

Gambar. Kaitan Khusus Brand, Positioning, dan Differentition

Agar janji yang terumus di dalam positioning memiliki kredibilitas dan di persepsi positif oleh pelanggan, maka janji tersebut harus didukung oleh diferensiasi yang kuat. Bagaimana Kawasan Pariwisata Bojonegoro membangun diferensiasi tersebut? Ia sangat serius menerapkan "one-stop-shopping services ", mendorong penerapan teknologi untuk mendukung layanan pelanggan, menyusun program ' Pesona Wisata yang Cantik Alami' agar tetap mempesona. Dan didukung oleh keramahan penduduk yang "welcome".

Positioning yang didukung oleh diferensiasi yang kokoh akan menghasilkan brand integrity yang kuat. Brand integrity yang kuat ini pada gilirannya akan menghasilkan brand image "Bojonegoro MATOH" yang kuat. Dan pada akhirnya, brand image yang kuat akan memperkuat positioning yang telah ditentukan sebelumnya.

Bila proses diatas berjalan dengan mulus, ini akan menciptakan apa yang disebut dengan "self-reinforcing mechanism" atau proses penguatan secara terus menerus di antara ketiga unsur strategic place triangle di atas. Proses penguatan ini akan berulang secara terus menerus, semakin membesar dan terus saja membesar seperti luncuran bola salju yang bergulung-gulung dari atas ke bawah. Karena proses penguatan ini, maka kemudian ketiga unsur tersebut menjadi semakin solid, dan pada gilirannya akan menjadi landasan bagi penguatan keunggulan kompetitif kawasan pariwisata Bojonegoro. 


\section{KESIMPULAN}

Dari hal tersebut dapat ditarik benang merah sebagai berikut:

1. Dari analisis pemetakan terhadap pesaing dan pelanggan kawasan pariwisata Bojonegoro didapatkan bahwa diantara empat pesaing (Banyuwangi, Lamongan Malang, dan Tuban,) pesaing utama Bojonegoro adalah Banyuwangi. Sementara analisis terhadap pelanggan kawasan pariwisata Bojonegoro didapatkan bahwa: pelanggan semakin tinggi tuntutannya, pelanggan sensitif terhadap isu-isu yang berkembang, pelanggan tidak lagi memiliki loyalitas, tumbuhnya investor level nasional.

2. Positioning yang didukung oleh diferensiasi yang kokoh akan menghasilkan brand integrity yang kuat. Brand integrity yang kuat ini pada gilirannya akan menghasilkan brand image " Bojonegoro MATOH" yang kuat. Dan pada akhirnya, brand image yang kuat akan memperkuat positioning yang telah ditentukan sebelumnya.

3. Bila proses diatas berjalan dengan mulus, ini akan menciptakan apa yang disebut dengan "self-reinforcing mechanism" atau proses penguatan secara terus menerus di antara ketiga unsur strategic place triangle di atas. Proses penguatan ini akan berulang secara terus menerus, semakin membesar dan terus saja membesar seperti luncuran bola salju yang bergulung-gulung dari atas ke bawah. Karena proses penguatan ini, maka kemudian ketiga unsur tersebut menjadi semakin solid, dan pada gilirannya akan menjadi landasan bagi penguatan keunggulan kompetitif kawasan pariwisata Bojonegoro.

\section{SARAN}

Ada beberapa hal yang ingin peneliti sampaikan dalam saran ini yaitu :

1. Pendekatan yang selama ini digunakan adalah pendekatan sektoral dan spasial dalam memasarkan potensi kawasan pariwisata Bojonegoro atau lebih bersifat inward looking yaitu hanya melihat potensi yang dimiliki oleh kawasan itu, tapi kurang memperhatikan sudut pemasaran itu sendiri (outward looking). Sehingga pendekatan Strategi Pemasaran Wilayah (Marketing Places) dapat diterapkan dalam mengembangkan kawasan pariwisata Bojonegoro. 
2. Daerah sudah harus menggeser pendekatannya dalam mengelola dan mengembangkan kawasan pariwisata Bojonegoro, dari pendekatan yang birokratis ke pendekatan strategic-entrepreneurial. Pendekatan birokratis melulu berorientasi pada prosedur dan aturan baku birokratis yang menyebabkan suatu kawasan kehilangan kepekaan terhadap kebutuhan konstituennya. Sementara pendekatan strategic-entrepreneurial, bersifat pragmatis karena selalu berorientasi hasil dan peka terhadap setiap peluang, selalu fokus pada kebutuhan dan ekspektasi konstituennya, dan yang tidak kalah penting pendekatan ini responsif terhadap setiap perubahan yang terjadi dalam lingkungan makro.

3. Kita harus dapat membangun budaya entrepreneurial bukan budaya birokratis. Karena sebagus apapun strategi akan menjadi sia-sia jika nilai-nilai (share values) dan perilaku (common behavior) yang berkembang di dalam organisasi pemerintahan masih bersifat birokratis.

\section{DAFTAR PUSTAKA}

Alex S. Nitisewito, Marketing, ghalia Indonesia, Jakarta, 1991. 2.

Alkadri, dkk, Manajemen Teknologi Untuk Pengembangan Wilayah,- Konsep Dasar, Contoh Kasus,dan Implikasi Kebijakan-, Penerbit Pusat Kajian Kebijakan Teknologi Pengembangan Wilayah (P2KTPW) BPPT, Jakarta, 2001.

Basu Swasta DH dan Irawan, Manajemen Pemasaran Modern, Edisi kedua, Liberty, 1992

Basu Swastha DH, Azas-azas Marketing, Ghalia Indonesia, Jakarta, 1988

Dwijowijoto, Riant Nugroho, Kebijakan Publik- Formula,Implementasi, dan Evaluasi-, PT. Alex Media Komputindo, Jakarta, 2003

Hunger J. David \& Thomas L Wheelen, Manajemen Strategis, Penerbit ANDI, Yogyakarta, 2003

Kartajaya Hermawan, dan Yuswohadi, Attracting- Tourists, Traders, InvestorsStrategi Pemasaran Daerah di Era Otonomi, Gramedia Pustaka Utama, Jakarta, 2005.

Kartajaya Hermawan, Perjalanan Pemikiran Konsep Pemasaran, Penerbit Erlangga, Jakarta 2010 
Kountour, Ronny, Motede Penelitian,- Untuk Penulisan Skripsi dan Tesis,Penerbit PPM, Jakarta, 2004.

Peraturan Daerah Propinsi Jawa Timur Nomor 8 Tahun 2005, RPJMD Prop. Jawa Timur Tahun 2006 - 2008.

Nawawi Hadari, Manajemen Sumber Daya Manusia untuk Bisnis yang Kompetitif, Gadjah Mada University Press, Yogyakarta 2001

Nasir Moh, Metode Penelitian, Ghalia Indonesia, Jakarta, 1999

Newwave Marketers, edisi September 2010, artikel tentang : "From Product to Co-Creation, From Citizen to Netizen”. Abdi R. Sastrawinata

Nurif Muchammad, Analisis Model Strategic Places Triangle untuk Pengembangan Kawasan Pariwisata, dalam Jurnal Manajemen \& Bisbis Terakreditasi Volume 6 Nomor 1 2007, ISSN 1412-3789

Peraturan Daerah Kabupaten Bojonegoro No. Tahun 2013 tentang, Rencana Pembangunan Jangka Menengah Daerah (RPJMD) Kabupaten Bojonegoro tahun $2013-2018$.

Phillp Kotler, Marketing Management, Prentice-Hall International, Inc., 2003.

Phillip Kotler, dkk, Rethinking Markerting - Sustainable Market-ing Entreprise di Asia, PT. Prenhallindo, Jakarta, 2003. Philip Kotler, dkk, Marketing Asian Places - Attracting Invesment, Industry, and Tourism to Cities, States and Nations, John Wiley \& Sons (Asia) Pte Ltd, 2002.

Stoner James A.F., dan R. Edward Freeman, Management, Intermedia, Jakarta, 1994. 